\title{
Opacidad y transparencia del Caribe en las representaciones de Yucatán. Dos casos de cultura visual*
}

\begin{abstract}
Maricruz Castro Ricalde
Afiliada institucionalmente como profesora investigadora del Tecnológico de Monterrey (México). Correo electrónico: maricruz.castro@tec.mx. La autora es doctora en Letras Modernas por la Universidad Iberoamericana (México) y es miembro del Sistema Nacional de Investigadores, nivel II, y la Academia Mexicana de Ciencias. ORCID ID: https://orcid.org/0000-0002-2396-9207. Recientemente ha publicado, entre otros: "El feminismo y el derecho al sufragio en la prensa mexicana. Los cartones (1939-1940) de Ernesto ‘El Chango' García Cabral”. Hispanófila 186 (2019), “Cecilia Pego: novela gráfica, violencias y neocolonización". Bulletin of Hispanic Studies 96.3 (2019) y "Literatura y autoría en el cine mexicano". Cuadernos de Literatura 22.44 (2018). Entre sus temas de interés se encuentran Estudios de género, Cultura visual, audiovisual y literaria en México y Latinoamérica, siglos XX y XXI.
\end{abstract}

Recibido: 2 de diciembre de 2018

Aprobado: 12 de marzo de 2019

Modificado: 6 de abril de 2019

Artículo de investigación científica

DOI: http://dx.doi.org/10.15648/hc.37.2020.6

\footnotetext{
* $\quad$ Este artículo forma parte del proyecto "Representaciones literarias de insularidad en escritores de Yucatán, Belice y Guyana. Hacia un modelo para el Caribe continental (Conacyt CB257673)" financiado por el Consejo Nacional de Ciencia y Tecnología - CONACYT Ciencia Básica 2015 (México). Esta publicación está bajo una licencia Creative Commons Reconocimiento-NoComercial 4.0
} 
Opacidad y transparencia del Caribe en las representaciones de Yucatán. Dos casos de cultura visual

\title{
Resumen
}

En este artículo reflexiono sobre los imaginarios en torno a la península yucateca de México, la relación con sus límites costeros y su adscripción caribeña. Expongo las transformaciones experimentadas entre 1921 y 1948, a partir del análisis de notas periodísticas, películas y cromos de calendarios. Basándome en las nociones de "transparencia" y "opacidad" propuestas por Édouard Glissant y de los modos de circulación cultural "desde arriba" y "desde abajo" de Ricardo Pérez Montfort y Christian Rinaudo, desarrollo la hipótesis de cómo cuestiones económicas y políticas determinaron el desplazamiento de las imágenes sobre Yucatán de sus litorales hacia el centro de la península y su zona arqueológica más conocida, Chichén Itzá. Sin embargo, en múltiples expresiones populares y específicamente en los cromos de los calendarios persistieron los indicios sobre su identificación con el trópico y la herencia cultural compartida con el Caribe.

Palabras clave: cultura visual, Yucatán, Caribe, identidades regionales, Cromos de calendarios en México

\section{Caribbean opacity and transparency in the representations of Yucatan. Two} cases from visual culture

\begin{abstract}
This paper discusses the imaginary arising around the Yucatan peninsula of Mexico, the relationship with its coastal boundaries and its Caribbean affiliation. From the analysis of journalistic notes, films and calendar illustrations, I present the transformations experienced between 1921 and 1948. Based on the notions of "transparency" and "opacity" proposed by Édouard Glissant and the modes of cultural circulation "from above" and "from below" by Ricardo Pérez Montfort and Christian Rinaudo, I develop the hypothesis of how economic and political issues have determined the displacement of Yucatan images, from its shores towards the Peninsula center and its best-known archeological zone, Chichén Itzá. However, in many popular expressions and specifically in the popular illustrations of the calendars, traces of their identification with the tropics and a cultural shared heritage with the Caribbean persisted.
\end{abstract}

Keywords: visual Culture, Yucatan, Caribbean, Regional identities, Mexican Calendar Art/Illustrations. 
Opacidade e transparência do Caribe nas representações de Yucatán. Dois casos de cultura visual

\section{Resumo}

No presente artigo faço uma reflexão sobre os imaginários em relação à península de Yucatán no México, a relação com seus limites costeiros e sua afiliação caribenha. Se mostram as transformações ocorridas entre 1921 e 1948, partindo da análise de jornais, filmes e imagens. Se prossegue à análise com as noções de "transparência" e "opacidade" propostas por Édouard Glissant e dos modos de circulação cultural em termos simples e detalhados de Ricardo Pérez Montfort e Christian Rinaudo, desenvolvendo uma hipótese de como as questões econômicas e políticas determinaram o deslocamento das imagens sobre Yucatán, em particular de seus litorais até o centro da península e de sua zona arqueológica mais conhecida, Chichén Itzá. No entanto, múltiplas expressões populares e especificamente nos calendários persistiram indícios sobre a identificação com os trópicos e a sua herança cultural compartilhada com o Caribe.

Palavras-chave: cultura visual, Yucatán, Caribe, identidades regionais, calendários no México.

\section{Opacité et transparence des Caraïbes dans les représentations du Yucatan. Deux cas de culture visuelle}

\section{Résumé}

Dans cet article, je réfléchis sur les imaginaires autour de la péninsule du Yucatan au Mexique, la relation avec ses limites côtières et son affiliation caribéenne. J'expose les transformations vécues entre 1921 et 1948, à partir de l'analyse de notes journalistiques, de films et de cartes de calendriers. Sur la base des notions de «transparence» et d'»opacité» proposées par Édouard Glissant et des modes de circulation culturelle «d'en haut» et «d'en bas» de Ricardo Pérez Montfort et Christian Rinaudo, je développe l'hypothèse selon laquelle les questions économiques et politiques ont déterminé le déplacement des images sur le Yucatán de ses littoraux vers le centre de la péninsule et sa zone archéologique la plus connue, Chichen Itza. Cependant, dans de nombreuses expressions populaires et plus particulièrement dans les chromes des calendriers, des indices persistèrent sur leur identification avec le tropique et l'héritage culturel partagé avec les Caraibes.

Mots clés: Culture visuelle, Yucatan, Caraibes, Identités régionales, Cartes de calendrier au Mexique 


\section{INTRODUCCIÓN}

Los estereotipos visuales que representan al Caribe así como la vigencia de lo que simbolizan, a través de diversos mecanismos de representación, se sintetizan en elementos muy puntuales: vegetación (palmeras), paisaje marino, movimiento (en sujetos que bailan), objetos (ciertos instrumentos musicales) y cuerpos que subrayan su herencia africana ${ }^{1}$. Sin embargo, cuando se exploran ciertos productos visuales provenientes de la cultura popular, cuyo propósito fue referirse a la península de Yucatán, en un período tan significativo como el del proyecto nacional, dichos elementos están ausentes. Este vacío podría explicarse en virtud de un momento histórico en el que la necesidad de afirmación nacional, en prácticamente toda Latinoamérica, tendió a separar y diferenciar regiones que siglos atrás habían mantenido estrechas relaciones en múltiples ámbitos y vertientes. Desde la academia, tal circunstancia repercutió fuertemente, pues durante décadas el Caribe se estudió desde una perspectiva netamente insular ${ }^{2}$.

Aproximarse a las ilustraciones de los calendarios creadas entre los años cuarenta y principios de los cincuenta del siglo XX, desde el centro del país ${ }^{3}$, a partir de la comprensión de Yucatán como parte del Gran Cari-

1 Ricardo Pérez Monfort, Expresiones populares y estereotipos culturales en México. Siglos XIX y XX: diez ensayos (México: CIESAS, 2007), 175-211; Gabriela Pulido Llano, "Atmósferas tropicales y pieles al carbón", Revista de la Universidad de México Nº 615 (2002): 33-39; Gabriela Pulido Llano, Mulatas y negros cubanos en la escena mexicana 1920-1950 (México: INAH, 2010).

2 "Tradicionalmente, en las ciencias sociales, los estudios culturales y literarios se han pensado el Caribe y Centroamérica como (sub)regiones separadas, excluyendo así las zonas caribeñas de América Central de un concepto del Caribe limitado al mundo insular. Los discursos científicos y artísticos del y sobre el Caribe y Centroamérica han sido caracterizados por una exclusión mutua". Werner Mackenbach, "Del éloge de la creolité a la teoría del caos. Discursos poscoloniales del Caribe más allá de la identidad", Cuadernos Intercambio 11 (2013): 15. Caisso indica que las lecturas desde la economía incidieron en dos rasgos característicos: la plantación y "la playa turística internacional". Claudia Caisso, "El caribe en sombras", Revista Universum 25.2 (2010): 15. Esta rígida perspectiva, "tradicional y más bien conservadora", ha sido desplazada por una mirada "transreal": "un concepto dinámico y vectorial de espacio que transciende las coordenadas geográficas estáticas". Ottmar Ette, Werner Mackenbach, Gesine Müller y Alexandra Ortiz Wallner (Eds.), Trans(it)Areas. Convivencias en Centroamérica y el Caribe. Un simposio transreal (Berlín: edition tranvía Verlag Walter Frey, 2011), 9 .

3 Me adhiero a la siguiente concepción de "centro": es tanto un lugar (la ciudad de México) como "un aparato institucional de poder que toma decisiones" y "un conjunto de discursos culturales 'nacionales". Jeffrey W. Rubin, "Descentrando el Régimen: Cultura y Política regional en México", Relacio- 
be, invita a plantearse distintas preguntas. La mía cuestiona la constancia formal y temática de las imágenes sobre la península que provenían de la capital mexicana y la elusión en ellas de los símbolos visuales asociados tradicionalmente con el Caribe, a pesar de los reiterados vínculos existentes entre ambos enclaves ${ }^{4}$. Al respecto, planteo que decodificar desde otro ángulo analítico dichas representaciones visuales funcionaría como una lectura práctica de la noción de "opacidad" propuesta por Edouard Glissant, en relación con el Caribe. Gracias a este concepto, evitaríamos caer en "la tentación de clasificar los modos de ser" de sus habitantes, de inmovilizar sus identidades 5 . Opacidad que, por lo tanto, se contrapone a la indiferenciación, a la homogeneización, la cual, si bien es necesaria para un consumo global, reduce, cierra y modela a medida $^{6}$. Al justificar la necesidad de dicha noción, Glissant abundó: las culturas occidentales "han desarrollado un concepto de transparencia de la humanidad al cual han de ajustarse todos los hombres y todas las mujeres del mundo. Algunos están cerca del modelo y otros están lejos de él. El problema de este concepto de transparencia es que toda la gente debe corresponder con su modelo"7 . Los casos que abordaremos

nes. Estudios de historia y sociedad Vol. XXIV No 96 (2003): 129. De aquí mi interés por delimitar la temporalidad de los ejemplos que forman parte de mi corpus de análisis, a fin de restringir tales discursos.

4 La bibliografía sobre las relaciones de todo tipo entre Yucatán y Cuba, principalmente, es muy vasta. Juan Gelpí, "El bolero en Ciudad de México: poesía popular urbana y procesos de modernización", Cuadernos de literatura Vol. 4 № 7-8 (1998): 197-212, ofrece atisbos al tránsito del bolero cubano al yucateco y a la ciudad de México. S. M. Wilson, H. B. Iceland \& T. R. Hester, T. R., "Preceramic connections between Yucatan and the Caribbean", Latin American Antiquity Vol. 9 N 4 (1998): 342-352, aventuran un probable origen yucateco y beliceño de los pobladores de las Antillas insulares. Ricardo Pérez Montfort, "Ecos del Caribe en la cultura popular y en la bohemia yucateca, 18901920", El Caribe: región, frontera y relaciones internacionales, coords. Johanna von Grafenstein y Laura Muñoz (México: Instituto Mora, Conacyt, 2000), 160-186, analiza los ecos del Caribe en la cultura popular yucateca. E. Cunin, "Negros y negritos en Yucatán en la primera mitad del siglo XX: Mestizaje, región, raza”, Península Vol $4 \mathrm{~N}^{\circ} 2$ (2009): 33-54, explora los vínculos entre los teatros regionales de Cuba y Yucatán. Victoria Novelo-Oppenheim, Yucatecos en Cuba. Etnografía de una migración (México: CIESAS/Instituto de Cultura de Yucatán: 2009), estudia la presencia de yucatecos en Cuba. Margaret Shrimpton Masson, "Islas de tierra firme: ¿un modelo para el Caribe continental? El caso de Yucatán”, Memorias Vol 11 No 25 (2017): 178-208, revisa la literatura yucateca y sus nexos con el Caribe, entre muchos otros.

5 Caisso, "El caribe", 15.

6 Édouard Glissant, Tratado del todo-mundo (Barcelona: El Cobre Ediciones, 1997), 31-32.

7 Ineke Phaf-Rheinberger, El lenguaje nación y la poética del acriollamiento. Una conversación entre Kamu Brathwaite y Édouard Glissant, en Memorias del silencio: literaturas en el Caribe y Centroamérica, comp. Graciela Salto (Buenos Aires: Corregidor, 2010), 28. En su charla con Brathwaite, 
están revestidos de una intención pragmática. Implica que mi punto de partida es la consideración de que la iconografía y las representaciones en general con las que se ha estereotipado el Caribe padecen de esa "transparencia". Esta impide ver y comprender la riqueza y la diversidad de la región, al circunscribirla a un imaginario básico: la voluptuosidad, "el jolgorio y la carnalidad atribuidos al trópico" se metamorfosean (aunque no desaparecen del todo) en una nueva "transparencia" con la que se inmoviliza lo yucateco.

La interpretación de Mackenbach sobre los presupuestos iniciales de Glissant da pauta para comprender de qué manera el Caribe se manifiesta, al margen de su iconografía más obvia: "La antillanidad es para él una posibilidad abierta. Está presente, existe en los hechos, pero al mismo tiempo está en peligro, es decir, todavía no está presente en la

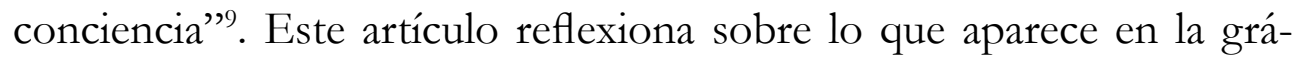
fica popular, en productos que estaban en sus márgenes (ninguna era pensada para ser exhibida sino para ser reproducidas masivamente), pero también en los elementos que circulaban "desde abajo". Con tal ausencia se ignoraron, consciente o inconscientemente, las "relaciones translocales familiares, de sociabilidad o de trabajo" con Yucatán de los compositores y los grupos musicales, de las bailarinas e intérpretes provenientes de, sobre todo, $\mathrm{Cuba}^{10}$. En cambio, privilegiaron una lógica de "circulación desde arriba", cercana a las industrias culturales del momento (radio, cine, producción discográfica, periódicos y revistas,

Glissant explica el contexto de los conceptos sobre las cuales hago descansar mi argumentación: cuando el de Martinica se inconforma con la manera como se está interpretando la teoría de la "créolité" se debió a su convicción de que "el acriollamiento es una noción que difracta", no es una de naturaleza concentradora y explicativa como las definiciones elaboradas desde la cultura occidental. La difractación, la inexplicabilidad, las incomprensibilidades son más acordes a las características de un proceso que no aspira a convertirse en un modelo de definición identitaria. De aquí la pertinencia de una "opacidad", gracias a la cual el sujeto reclama su derecho de no tener que comprenderse siquiera a sí mismo. Phaf-Rheinberger, El lenguaje nación, 28-29.

8 Maricruz Castro Ricalde, "Ninón Sevilla, el Caribe y la publicidad gráfica de la edad de oro", Hispania Vol. $100 \mathrm{~N}^{\circ} 4$ (2017): 609.

9 Mackenbach, "Del éloge de la creolité", 22.

12410 Ricardo Pérez Montfort y Christian Rinaudo, "Introducción”, en Circulaciones culturales, Lo afrocaribeño entre Cartagena, Veracruz y La Habana, coords. Freddy Ávila Domínguez, Ricardo Pérez Montfort y Christian Rinaudo (México: Ciesas, IRD, ANR, Universidad de Cartagena, El Colegio de Michoacán, 2011), 16. 
principalmente) estimuladas por intereses políticos, de Estado, de élites culturales así como de receptores que la aceptaban negociada, parcial o totalmente.

Este artículo también invoca a los estudios sobre cultura visual, gracias a los cuales las imágenes son leídas en función de su valor como productoras de significados que establecen y mantienen "aesthetic values, gender estereotypes and power relations within culture"11. La experiencia filtrada por las imágenes que nos circundan implica una mirada más abarcadora y cuya aproximación, necesariamente, debe ser interdisciplinaria. Ello invita a acercarse a productos culturales en los que, tal vez, la historia del arte no reparó. No obstante, la mera existencia de dichos productos culturales resalta su propia marginalidad, su función mediadora en cuanto a las relaciones sociales y el papel que desempeñan dentro de las prácticas tanto de su época como en el presente de quien las detecta. En esta línea y para lograr el objetivo propuesto, abordaré dos casos. El primero de ellos se refiere a la "Noche Mexicana" de 1921. Fue la primera celebración popular masiva en la Ciudad de México, desde los levantamientos armados de 1910. En esta cala pretendo mostrar cierta oscilación entre la transparencia y la opacidad, en relación con la península yucateca, al adjudicarle, simultáneamente, rasgos tradicionalmente "caribeños" y características indígenas. El siguiente corte analítico se detiene en una imagen que circuló sobre Yucatán en los cromos de calendarios, por parte de la empresa más exitosa de ese giro, Galas de México. El período que cubren ambos casos da cuenta del surgimiento y la consolidación del proyecto nacional, lapso en el que se "fijan" los imaginarios sobre las regiones, dentro de las cuales Yucatán es un paradigma en sí, dados sus antecedentes históricos ${ }^{12}$. Discutiré

11 Irit Rogoff, "Studying Visual Culture", en The Visual Culture Reader, editado por Nicholas Mirzoeff. (London: Routledge, 2002), 24.

12 La temporalidad escogida es una de las más estudiadas de la historia mexicana debido a su enorme riqueza cultural, la cual cosechó los beneficios de una paz más o menos generalizada en el territorio nacional. 1940 es un año decisivo porque no solo marca el fin del cardenismo sino "the end of the revolutionary promise", sustentada en acciones que tendían a redistribuir la riqueza en el país, a diferencia del siguiente sexenio (el de Manuel Ávila Camacho) "of intensive capital accumulation”. No obstante, la situación de reconstrucción europea y el papel de Estados Unidos en ella contribuyeron a prolongar el "milagro" del crecimiento económico que perduró hasta los años sesenta en México. Joseph Gilbert, Joseph, Anne Rubenstein y Eric Zolov, "Assembling the Fragments: Writing the Cultural History of 
cómo las reiteraciones visuales construidas desde el centro tienen un propósito sinecdótico con el que economizaron la diversidad nacional y la pusieron al alcance de la comprensión local e internacional, en un lapso inquietante en lo económico y lo social. Mi narrativa se desarrolla, entonces, en el movimiento oscilatorio de Yucatán que de ser un límite costero pasa a ser leída como una civilización perdida en la selva. Mis aproximaciones se cimentan en los estudios sobre cultura visual y aluden a ejemplos poco abordados por la crítica académica.

\section{Yucatán en el concierto de la "Noche Mexicana"}

El deseo de transmitir a la ciudadanía un sentimiento unificador, en torno a la idea de lo que era ser mexicano, tuvo un momento significativo en el temprano período posrevolucionario". En 1921, se celebró la "Noche Mexicana", de manera masiva y planeada cuidadosamente desde, por lo menos, seis meses atrás por una élite intelectual y empresarial que trató de impulsar "la creación de imaginarios de un público en torno a una idea de nación" ${ }^{14}$. El resultado fue la primera fiesta nacional organizada desde el estallido revolucionario que contribuyó a consolidar la "construcción cultural de lo típico"15. En ella, hubo un intento explícito de recrear las ferias de algunos lugares de la provincia mexicana. Su impacto fue tal que, formalmente, sentó las bases de los espectáculos contemporáneos de los llamados días patrios: desde un ánimo popular y multitudinario; con el lucimiento de estampas regionales, a partir del tipo de indumentarias con que se animaba a asistir; con un programa de entretenimiento que ofrecía espectáculos dancísticos y musicales ligados a la nación así como mues-

Mexico since 1940", en Fragments of a Golden Age: The Politics of Culture in Mexico Since 1940, eds. Joseph Gilbert, Joseph, Anne Rubenstein y Eric Zolov (USA: Duke University Press, 2001), 8.

13 El término "posrevolucionario" no necesariamente debe reducirse a una cuestión temporal (el período posterior al fin del movimiento armado). Conceptualmente es de gran productividad si, siguiendo sus razonamientos, se estudia como "an opportunity to formulate a new set of cultural ideals, as well as repackaging many Porfirian ideals and infusing them with new urgency." Esto implica la necesidad de considerar el rol desempeñado por un gran número de actores sociales que involucran intelectuales, políticos, periodistas, artistas, sectores de la clase popular. Ricardo A. López, Crafting Mexico: Intellectuals, Artisans, and the State after the Revolution (Durham: Duke University Press, 2010), 6.

14 Esa fiesta masiva fue la primera convocada en la ciudad de México, en diez años, debido a que el movimiento revolucionario implicó la suspensión de un gran número de actividades públicas en espacios abiertos. Manuel R. Cuéllar, "La escenificación de lo mexicano y la interpelación de un público nacional: la Noche Mexicana de 1921", en Mexican Transnational Film and Literature, eds. Maricruz Castro Ricalde, Mauricio Díaz Calderón y James Ramey (Oxford: Peter Lang, 2017), 124-125. 
tras de su gastronomía. Estas celebraciones constituyeron "parte central de los elementos definitorios de lo que se consideraba 'mexicano', es decir: 'lo propio' o 'lo auténtico’ de México"'16.

Los reportes de la prensa de la época hablaron de una asistencia de aproximadamente 200 mil personas que se dieron cita en el Bosque de Chapultepec. Según la Comisión de Festejos, su objetivo fue mostrar "el alma de la República, dispersa y casi olvidada por los intelectuales exóticos"17. La visión esencialista sobre la nación, transparentada en esa búsqueda del "alma" mexicana, también se condensó en la identificación de los grupos demográficos que a juicio de los organizadores, mejor la representaban. Sí, por supuesto, no podían faltar las chinas poblanas, "las yucatecas mostraron a los ojos asombrados de varios miles de personas el caudal de su tradición y la gracia exquisita de su raza", se narraba en el $E l$ Universal Ilustrado. Otras regiones fueron representadas en ese evento, de acuerdo con la nota periodística: Oaxaca, a través de las tehuanas; Sinaloa, mediante la pascola yaqui (la danza del venado) así como las chinas

16 Pérez, Expresiones populares, 120. Este acontecimiento formó parte de un conjunto más amplio de esfuerzos, en pos del mismo objetivo: "En 1921, con motivo de los festejos del centenario de la consumación de la independencia, el nuevo gobierno encabezado por el presidente Obregón reconoció en forma pública su admiración por las artesanías indias que a partir de entonces tendrían un lugar privilegiado en el discurso nacionalista". Victoria Novelo-Oppenheim, "De revoluciones y cambios culturales: Yucatán 1915-1929", LiminaR, Vol 10 Nº 2 (2012): 180.

17 "La 'Noche Mexicana' en el Bosque de Chapultepec", El Universal Ilustrado, Ciudad de México, 29 de septiembre, 1921, 26. La anónima nota periodística muy posiblemente alude a los intelectuales del porfiriato, los "científicos", quienes en un manifiesto publicado en 1892 especificaban la necesidad de elevar moral e intelectualmente "a los sectores más populares". Charles Hale, La transformación del liberalismo mexicano en el último cuarto del siglo XIX (México: Editorial Vuelta, 1991), 180. Habría que tener en mente, sin embargo, que Porfirio Díaz, como parte de su estrategia política de debilitamiento de los caciques locales, impulsó "la cultura nacionalista con el culto a los héroes nacionales (principalmente con la figura de Juárez)". César Arturo Velázquez Becerril, "Intelectuales y poder en el Porfiriato. Una aproximación al grupo de los Científicos, 1892-1911", Fuentes Humanísticas $\mathrm{N}^{\circ} 41$ (2010): 20. La "exotización" de los intelectuales del porfiriato estaría ligada al afrancesamiento de su educación y sus gustos, el cual funcionaba a la perfección como noción antagónica esgrimida por la nueva clase política surgida de la lucha armada o bien, consolidada después de esta. En esos meses, el Ministro de Educación José Vasconcelos había arreciado su discurso en contra de la imitación de lo francés y lo inglés y promovía un mestizaje que incluyera "las distintas razas que forman nuestra nacionalidad". En noviembre de 1921, en su visita a Yucatán, Vasconcelos se hizo acompañar de Diego Rivera, quien también criticó "a los artistas e intelectuales que tenían la vista puesta en el extranjero". Novelo-Oppenheimer, "De revoluciones", 182, 183. 
poblanas $^{18}$ y Yucatán ${ }^{19}$. Esta selección indica, por sí misma, qué grupos estuvieron simbólicamente invitados a lo que se iría convirtiendo, en las siguientes décadas, en el "banquete" de la identidad nacional.

\section{Figura 1}

Fotografía con la que se ilustraron las "bailadoras de extrañas danzas de esa península privilegiada".

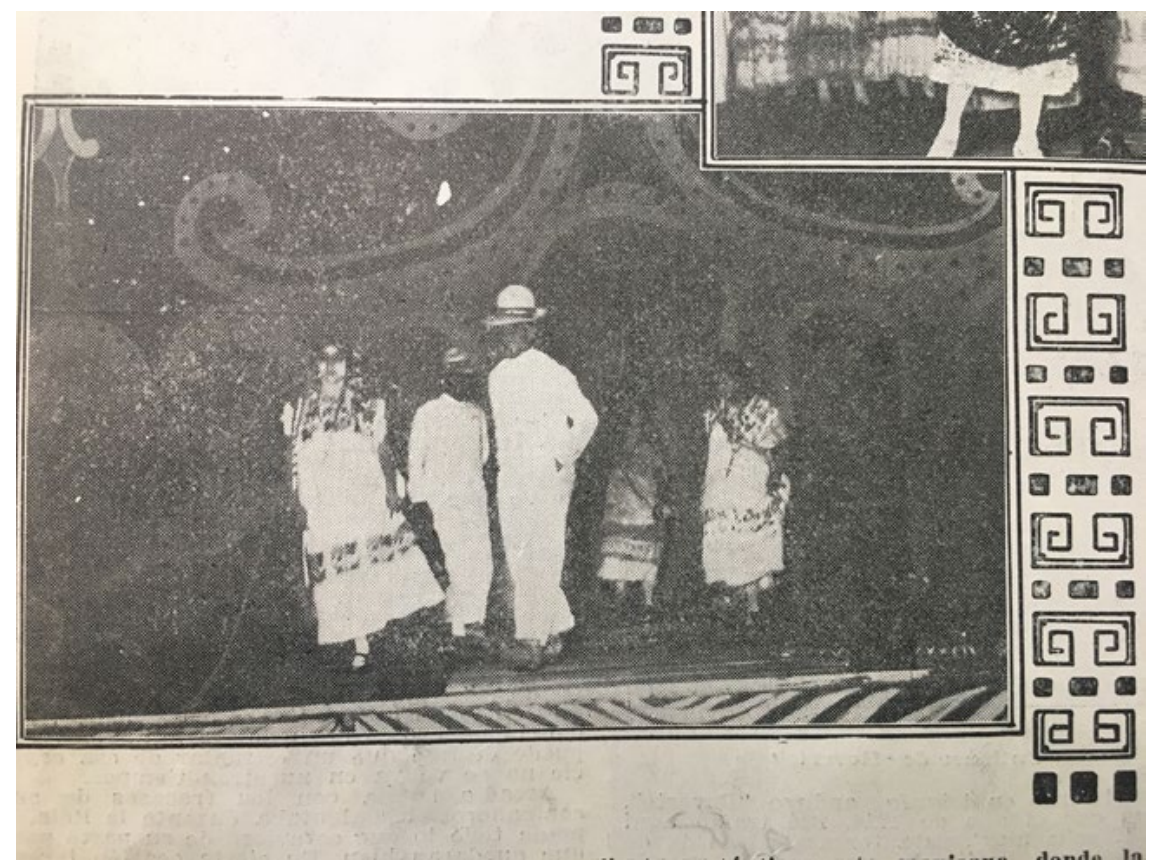

Fuente: Imagen cortesía de: Biblioteca Lerdo de Tejada, de la Secretaría de Hacienda y Crédito Público (México).

De la reseña anterior se infiere la lejanía existente entre la Ciudad de México y algunos de los enclaves geográficos de la república, pero también de la distancia informativa sobre las regiones, entre los pobladores

18 El personaje de la China Poblana, al bailar el Jarabe Tapatío, condensa dos de las regiones políticamente más importantes: Puebla y el Bajío, aunque este se refiriera básicamente a Jalisco. El cine mexicano, al emparejar románticamente a la China con el charro, terminará por consolidar una estampa originada a principios de siglo y desplazará la mirada hacia un Jalisco imaginario que parecía abarcar a toda la nación en sus paisajes, sus actividades y sus diversiones. Guillermo Sheridan, México en 1932: la polémica nacionalista (México: Conaculta, Ediciones sin nombre, 2004), 102. Para un estudio más detallado consúltese: Guillermo Pérez Montfort, "La china poblana. Notas y breve crónica sobre la construcción del estereotipo femenino nacional”, en Expresiones, 119-146.

"La 'Noche Mexicana”, 27. 
de la capital mexicana. De aquí que los asistentes atestiguaran cuadros vivientes con "los ojos asombrados" de quienes no conocen o identifican lo que ven. A través de cierto vestuario y un tipo concreto de danzas se condensaba la "tradición" de la cultura de cada región. Quienes provenían de Yucatán fueron asociados con los grupos indígenas mayas; de ahí que se hablara de "la gracia exquisita de su raza". La nota añadió cómo: "Yucatán trasladó un poco de su espíritu al bosque milenario, enviando bailadoras de extrañas danzas de esa península privilegiada" ${ }^{20}$. Así, lo que esa noche se experimentó fue un "encanto auténticamente mexicano" $"$.

En los extractos de ambos escritos periodísticos, es notoria la oscilación con que son nombrados los colectivos que provienen de distintas partes del país. Es decir, el empleo de gentilicios ("yucatecos"), denominaciones étnicas ("yaquis"), según el traje que portan ("tehuanas" o "chinas poblanas") así como sustantivos con sesgos fuertemente ideológicos como "nativos" e "indios" aparecen indistintamente para designar a quienes formaron parte de los cuadros festivos. Se toman como sinónimos "etnia", "raza" y habitantes de una región por lo que ser yucateco implica pertenecer a una "raza", a partir del entendido (producto de la poca importancia dada al uso de tales términos) de que todas las personas oriundas de la península del sureste eran mayas. Así, ideas como la existencia de "el alma de la República" y de su condición "dispersa y casi olvidada", aunque podían haber sido generadas desde la élite política y cultural del momento, fueron diseminadas y contribuyeron a su consolidación debido a que los discursos de la prensa (y los medios de comunicación en general) las adoptaron sin resistencia alguna. Esto confirma la relatividad del poder del Estado posrevolucionario y de

20 La imagen del bosque como metáfora de un lugar apartado y mágico indica tanto el desconocimiento del suelo y la flora de la península yucateca como la interpretación sobre las regiones lejanas y de las cuales se sabía poco, culturalmente hablando. Es evidente que la prevalencia de lo maya en Yucatán inducía a conformar un imaginario que invocaba al estereotipo de lo primitivo, lo oculto y lo misterioso. Más adelante abundaré al respecto, cuando analice el cromo de Jesús Helguera, "La Xtabay". 
cómo este necesitaba de la aceptación (no necesariamente fruto de la coerción) de múltiples actores sociales ${ }^{22}$. Según veremos en el siguiente apartado, tal aquiescencia también procedía de las creaciones populares emanadas del centro del país (y por lo tanto, las circulaciones de los imaginarios eran múltiples) como también de las regiones a las que estas aspiraban representar (Yucatán adopta las imágenes que ligan a la península con la indistinción de "lo maya" y "lo yucateco") 23 .

Son claras otras ideas que articulan el binomio región/nación, en el marco de esa reseña. Por un lado, la diversidad del suelo nacional que conduce al azoro ante lo que no se sabe y que entraña poner en marcha estrategias de familiarización como parte de "un proceso en el que los individuos interiorizan las normas, las categorías y las estructuras del estado nacional al punto de convertirlas en un componente de la identidad personal" 24 . Se asentaba así el sureste mexicano como un lugar exótico pero también, por el otro lado, se iban construyendo ideas que ligaban lo peninsular con la excepción y la riqueza de la zona. Su distancia geográfica era tan real como magnificada por un imaginario

22 La gran respuesta al festejo, con decenas de miles de personas acudiendo a él, el asombro con que fueron recibidos los bailes y las estampas regionales, al igual que la ausencia de reclamos sobre los espectáculos montados son indicadores del beneplácito popular. Este es un sencillo ejemplo de la multidireccionalidad ideológica y cultural sobre la cual terminaron por consolidarse los imaginarios sobre las regiones, aun cuando sigue siendo válida la precaución solicitada por Joseph y Wells sobre "qué tiene de popular lo popular", a fin de evadir enfoques esencialistas. G. M. Joseph y A. Wells, "Un replanteamiento de la movilización revolucionaria mexicana: los tiempos de sublevación en Yucatán, 1909-1915”, Historia Mexicana Vol. XLIII Nº 3 (1994): 539.

23 Esta es la tesis de Rubin: "el régimen posrevolucionario autoritario y hegemónico" solo puede aceptarse de una manera localizada (en circunscripciones geográficas más o menos delimitadas culturalmente) y tomando en cuenta factores como "prácticas de etnicidad, lenguaje, género, religión e identidad cívica". Para ello se necesitan negociaciones múltiples así como ceder a ciertas coerciones o formar alianzas con múltiples instituciones y actores sociales de las regiones. Rubin, "Descentrando el Régimen", 128.

13024 Claudia Dávila Valdés, "Necesitamos extranjeros. Libaneses y coreanos en la sociedad yucateca”, en Miradas regionales. Las regiones y la idea de nación en América Latina, siglos XIX y XX, comps. Jorge Arturo Taracena Arriola, María Carolina Depetris y Adam Sellen Temple (México: UNAM, 2013), 103. 
que iba tejiendo múltiples asociaciones. Algunas de ellas: el asombro, la extrañeza, la "gracia exquisita" y lo privilegiado de la región yucateca ${ }^{25}$.

Por su parte, el periodista Manuel Palavicini ofreció su versión de dicha fiesta popular en la primera sección del periódico El Universal. Me interesa resaltar cómo describe uno de "los bailes nacionales" ejecutados por "nativos": "Los yucatecos, con la música lenta y lasciva de las costas, que lleva quejas mezcladas con notas distintas que interrumpen el sentido general de la música"26. La exotización también se presenta aunque de una manera muy singular: la alteridad de los habitantes de la península vinculada a una sensualidad "característica" del trópico. Este rasgo es, hasta cierto punto, sorprendente, pues a diferencia de puertos como Veracruz y Acapulco, los litorales yucatecos no figuraban, en esos años, como enclaves marítimos sobresalientes, dada su escasa actividad comercial y turística ${ }^{27}$. La fusión puerto/costa fue tal que las películas mexicanas de los años cuarenta y cincuenta situaron sus tramas "tropicales", principalmente, en uno u otro lugar. Algunos títulos a manera de ejemplo: Tierra Brava (René Cardona 1938), Hombres del mar (Chano Urueta 1938), Konga Roja (Alejandro Galindo 1943), La reina del trópico (Raúl de Anda 1945), Revancha (Alberto Gout 1948), Coqueta (Fernando A. Rivero 1949), Simbad el mareado (Gilberto Martínez Solares 1950), Sombra verde (Roberto Gavaldón 1954), ¡Qué bravas son las costeñas! (Roberto Rodríguez 1955), Acapulqueña (Ramón Pereda 1959).

25 Aunque la "edad de oro" del cultivo del henequén suele situarse entre finales del siglo XIX y 1915, unos años después seguramente persistía la convicción de la boyante situación económica en la península, máxime que esta no había participado directamente en las luchas armadas revolucionarias. Recordemos que "la gran mayoría de hacendados productores de henequén de Yucatán (los henequeneros) constituían una de las clases más adineradas de México durante el porfiriato”. Joseph y Wells, "Un replanteamiento", 511.

26 Manuel Palavicini, "La Noche Mexicana en Chapultepec", El Universal, Ciudad de México, 28 de septiembre, 1921, 2.

27 Los problemas de desarrollo de Yucatán se presentaron hasta por lo menos los años sesenta del siglo XX y se fincaron, principalmente, en "Isolation, and the lack of good natural harbours". Incluso en los años ochenta, "the Yucatan also remains peripheral to the mainstream economy". Michael Barke, "Merida, Yucatan: A core within the periphery", Scottish Geographical Magazine Vol. 100 N$^{\circ}$ 3 (1984), 162. 


\section{Figura 2}

Fotomontaje de la película Deseada (Fernando de Fuentes 1951). El tópico de Chichén Itzá como sinécdoque de la península yucateca

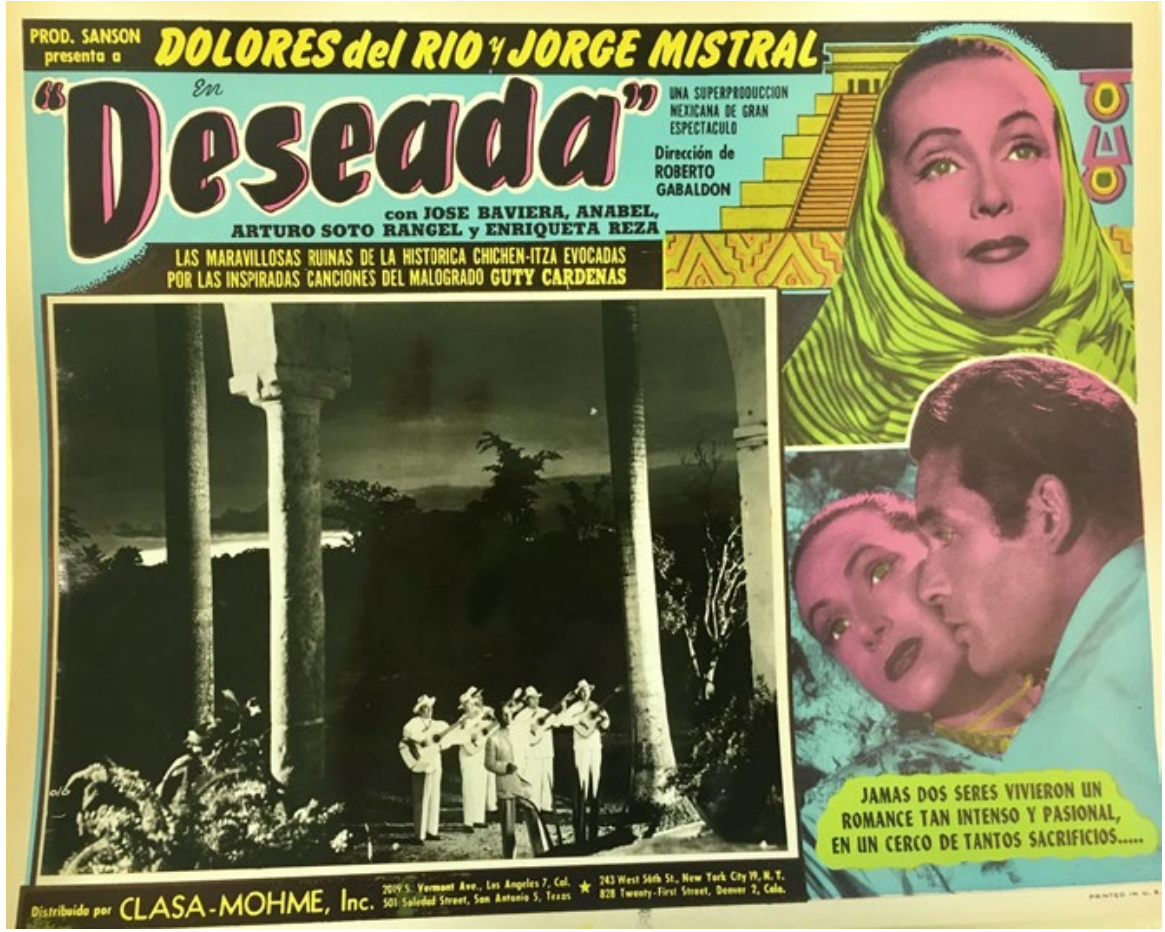

Imagen cortesía de: Agrasánchez Collection of Mexican Cinema.

En cambio, los filmes rodados en Yucatán o que se referían a esta entidad fueron: La Golondrina (Miguel Contreras Torres 1938), La noche de los mayas (Chano Urueta 1939), La selva de fuego (Fernando de Fuentes 1945), Deseada (De Fuentes 1951), Chilam Balam (Iñigo de Martino 1955). Los títulos mismos traslucen las asociaciones que prevalecían sobre esas regiones (las costas y la península desligada de sus litorales) así como la importancia de los personajes femeninos para las mismas. Los escasos largometrajes sobre Yucatán, durante la edad dorada, se justifican en razón de la complejidad que planteaba a las compañías productoras trasladarse a la península con el elenco programado para escenas en locación así como con el equipo necesario para el rodaje. Sí destacan, en cambio, los tópicos elegidos que, por lo menos como expectativa, auguraban la recuperación de lo invertido mediante la taquilla. En tres de ellos, la filmación fue en locaciones arqueológicas. 
En La Golondrina, el eco que la historia del celuloide levantaba en relación con Alma Reed y el gobernador yucateco asesinado en 1924, Felipe Carrillo Puerto ${ }^{28}$. Este romance había alcanzado niveles míticos tanto por la popular canción "Peregrina" como por las fantásticas especulaciones de que Carrillo Puerto había renunciado a liderar un levantamiento campesino con tal de reunirse en Estados Unidos con su amada $^{29}$. En La selva de fuego, los conflictos en los campos chicleros, en lo que hoy es el estado de Quintana Roo.

Este breve recuento sobre la cinematografía y su relación con las regiones pretende mostrar cómo, entre la recepción de la "Noche mexicana" de 1921 y el declive de la edad de oro del cine mexicano a mediados del siglo XX, la vinculación de Yucatán con la costa y los atributos estereotipados de esta se habían desvanecido. En cambio, se había afianzado la conexión de la península con lo maya (una época prehispánica imaginada) o con la dupla maya/mestiza ${ }^{30}$ (como ocurre en La noche de los mayas o Deseada) ${ }^{31}$. Es decir, con centros ligados tanto a algún tipo de

28 La orientación socialista de algunas de las medidas del período cardenista (1934-940) reactivó la memoria colectiva sobre Felipe Carrillo Puerto, quien gobernó Yucatán de 1922 a 1924. Fue fusilado junto con tres de sus hermanos y nueve miembros de su gabinete, a raíz de la inconformidad que levantó entre la oligarquía peninsular. Impulsó medidas puntuales como el reparto de la propiedad de la tierra, la regulación de la industria henequenera, el estímulo a la formación de cooperativas, el sufragio para las mujeres, entre muchas otras. Gilbert Joseph, "Mexico’s 'Popular Revolution': Mobilization and Myth in Yucatan, 1910-1940”, Latin American Perspectives Vol. 6 Nº 3 (1979): 46-65. Su idilio con la periodista del New York Magazine fue un escándalo, pues él tenía que divorciarse para legalizar su unión. Reed recibe la noticia del asesinato de Carrillo Puerto, mientras estaba en el extranjero comprando su ajuar de bodas y arreglando documentos personales. El idilio adquirió visos de leyenda debido a que el gobernador le había solicitado al famoso compositor Luis Rosado Vega una canción dedicada a su enamorada, la cual fue musicalizada por Ricardo Palmerín. "Peregrina" es reconocida hoy como una de las composiciones más idiosincráticas de Yucatán. Michael Schuessler, "Estudio preliminar", en Peregrina. Mi idilio socialista con Felipe Carrillo, Alma Reed (México: Diana, 2006), XIII-XXVII.

29 Joseph, "Mexico's 'Popular Revolution”", 59.

30 Conviene aclarar que el vocablo "mestiza" difiere del uso que, por ejemplo, le daba José Vasconcelos. En Yucatán es un "término con el que se designa localmente a las mujeres mayas". Cuando alguien que no se considera maya viste con traje de mestiza, realiza una representación; "hace el papel de" una mestiza. Manuel Jesús Pinkus Rendón, De la herencia a la enajenación. Danzas y bailes "tradicionales" de Yucatán (Mérida: UADY, 2005), 51.

31 En este trabajo no profundizaré en el análisis de los carteles cinematográficos en sí o su relación con la trama de los filmes que publicitaban. Sí me interesa señalar la repetida inclusión de Chichén Itzá en ellos y el haz de significaciones generadas desde distintos tipos de productos de circulación masiva. La asociación de Yucatán con su pasado prehispánico persistirá en películas posteriores como 
urbe o de civilización (la maya "remota" y la mestiza "contemporánea") que, de alguna forma, invitaban a imaginar el territorio mexicano como un continuum terrestre que anudaba, desde el centro del país, a una de sus provincias más distantes. De acuerdo con lo planteado por Shrimpton, se estaría considerando esta región desde una "visión externa" que "lleva a unirse con el centro, con el resto de México"32.

Sintetizo, entonces, este primer apartado. En él he procurado respaldar mi argumentación sobre las configuraciones visuales "transparentes" que, más o menos establemente, perdurarían sobre Yucatán hasta nuestros días: su larga e histórica relación con la costa es desplazada para privilegiar tropos que enfatizan la lejanía y el misterio, con lo cual la civilización maya se exotiza tanto como se congela en el tiempo, en virtud de la distancia tempo-espacial. La retórica de los litorales, que mantendría en los imaginarios las relaciones de la península con el Caribe, fue ocupada por Veracruz, en el lado oriental del país, y por Acapulco, en el occidental. Para representar paradigmáticamente a la nación, parecieran haberse escogido solo ciertas regiones y se hicieron de lado otras, al grado de eclipsarse por completo, incluso, etnias y entidades.

La creación de imágenes regionales, su circulación y apropiación, tenía dentro de sus propósitos proyectar una idea de cohesión y unidad, necesaria a nivel interno, pero también internacionalmente. Uno de sus valores es de orden político, pues en la medida en la que están más asentadas las identidades regionales, los consensos sociales suelen ser más expeditos (tanto a nivel local como fuera de él) ${ }^{33}$. De aquí la apretada selección de lo que sería puesto en escena en "La Noche Mexicana". En ella se aspiraba a construir una estructura "coherente" ante los espectadores que detonara un sentido de pertenencia cimentado en el orgullo por la variedad de suelos, la riqueza de su flora y su fauna, la abundancia de tradiciones. Pero también revela cómo los sistemas de sentido no

Peregrina (Mario Hernández 1974) y Rastro de sangre (Arturo Ripstein 1981) y se renovará con las telenovelas rodadas en la península y que tuvieron cierto auge, a partir de los años noventa del siglo pasado.

32 Shrimpton, "Islas de tierra firme", 183.

33 Radu Barna y Mircea Maniu, "Regional Identity: A prerequisite for any efficient change of the regional economic structure", Modelling the New Europe Vol. 20 N$^{\circ} 3$ (2016): 8. 
están inmóviles y, en cambio, sí se adaptan dependiendo de un conglomerado de necesidades. La constancia de la asociación del trópico con la lascivia se agudiza al subrayar el contexto de la lentitud musical y contrasta con lo que difícilmente se vincularía con los ritmos y los sonidos de los zapateos característicos de la jarana yucateca, ejercidos sobre los entarimados ${ }^{34}$. Lo que presenciaron los periodistas, entonces, fue filtrado por el tamiz de los imaginarios de la época. Según lo expuesto, a principios de los años veinte, Yucatán era identificado como una zona limítrofe, costera, y, por lo tanto, como una porción terrestre cercada por los mares de la nación.

\section{Yucatán EN los CROMOS DE CALENDARIO: ¿EN DÓNDE ESTÁ EL CARIBE?}

En 1931, México vivió una crisis económica tan severa que amenazó con poner en jaque una de las certezas sobre las cuales reposaba la relativa paz de su territorio: las bondades sociales y políticas aparejadas con los movimientos revolucionarios de una década atrás. La necesidad de que las regiones reconocieran el poder del Estado, afincado en el centro del país, era urgente, ante la posibilidad de nuevos brotes de descontento. El entorno internacional y, en concreto el estadounidense, no era el más favorable, pues resentía profundamente el quiebre de Wall Street de dos años atrás ${ }^{35}$. De aquí que primero surgiera la idea de impulsar una campaña de consumo comercial de "lo propio" que pronto se extendió, gracias a la aquiescencia mediática. Se trataba de construir "símbolos que inflamaran el fervor popular"36. Apenas un año después,

34 Las fotografías de la celebración en el Bosque de Chapultepec muestran a hombres y mujeres ataviados con el terno yucateco, destinado a las fiestas de gala (Ver Fig.1). Es poco probable que se desplegaran danzas prehispánicas mayas, no solo por lo poco que se sabe de ellas sino porque, en esa ansia de representatividad, la pascola yaqui se programó con el propósito de que lo indígena estuviera incluido. Sobre las danzas y bailes de Yucatán, véase: Pinkus, De la herencia a la enajenación, 29-116.

35 Desde 1926, la economía mexicana había mostrado un deterioro determinado por un desequilibrio en la balanza comercial y una caída en las ventas del petróleo. De tal forma que en 1931, después de la Gran Depresión, la tendencia se acentuó. Tres grandes factores fueron la "caída de las exportaciones, del crédito, de los ingresos fiscales y la ocurrencia de eventos extraordinarios" como la pésima cosecha de 1929 que no se compensó con la "extraordinariamente buena" de 1931. Enrique Cárdenas, "La economía mexicana en el dilatado siglo XX, 1929-2009", en Historia económica general de México, coord. Sandra Kuntz (México: El Colegio de México, 2010), 505, 507.

36 Eduardo Nivón Bolán y Xóchitl Ramírez Sánchez, "Identidad, nación y reforma del estado en Mé- 
a mediados de 1932, a causa de distintos factores disminuyó la demanda externa y empezaron a verse signos de recuperación ${ }^{37}$. Asimismo, una de las consecuencias de esta crisis fue la reconfiguración de los ámbitos financieros y políticos así como la relación de la figura presidencial con las "masas" 38 . La población probablemente asoció la mejoría económica con el éxito de la campaña de orgullo nacional. ${ }^{39} \mathrm{El}$ derrotero nacionalista, impulsado por el ideario de José Vasconcelos y las políticas culturales del Estado Mexicano del cardenismo, se centró en "la certeza de que existe 'lo nuestro'; el deber de explorar el territorio de las 'realidades cercanas'; la reivindicación del 'sentimiento nacional'; la afirmación de que hay una tradición más auténtica que otras" ${ }^{40}$. De aquí que las acciones encaminadas a fortalecer "lo nuestro" se manifestaran de formas múltiples hasta muy entrados los años cincuenta.

El papel que desempeñaron los calendarios de pared en México, en relación con el fortalecimiento de los imaginarios sobre la nación, fue sobresaliente. A fines del siglo XIX circularon en un formato parecido al de su lapso de mayor popularidad (fines de los años treinta hasta casi la década de los sesenta). Eran impresos en el que el cromo ocupaba las tres cuartas partes de su extensión y la zona inferior se destinaba para el "faldón" o "faldilla" preimpresa. Esta se pegaba o engrapaba y exhibía los días y los meses del año. La sección que se personalizaba, con la información comercial, solía situarse entre la faldilla y la ilustración. Sin embargo, conforme su éxito fue aumentando en todo tipo de establecimientos y las imprentas fueron modernizándose, los diseños fueron personalizándose $e^{41}$. Su ángulo publicitario atrajo a los dueños de

xico", en La identidad nacional mexicana como problema político y cultural. Los desafíos de la pluralidad, coords. Raúl Béjar y Héctor Rosales (Cuernavaca: UNAM, CRIM, 2002), 304.

37 Luis Anaya Merchant, La gran depresión y México, 1926-1933. Economía, institucionalización, impacto social (Cuernavaca: UAEM, 2015), 9-10.

38 Jorge Antonio Morales Alfaro, “¿De qué manera la Gran Depresión afectó la política mexicana? 1929-1934”, La Gaceta de Ciencia Política Vol. 9 N 1 (2012): 95.

39 "Tan serio asunto económico se deslizó con facilidad hacia el folclore y al nacionalismo acendrado pero eso sí, lleno de fervor patrio". Nivón y Ramírez, "Identidad”, 303.

40 Sheridan, México, 42.

13641 El carácter comercial y popular de estos impresos propició que ni se recolectaran ni fueran conservados por instituciones públicas y académicas. Han sido muy pocos los estudiosos que se han ocupado de este tema en México, con mayor o menor profundidad. Algunos de ellos son: Alfonso Morales Carrillo, "La patria portátil. 100 años de calendarios mexicanos", en La leyenda de los cromos. El 
los negocios, mientras que el informativo y, sobre todo, el decorativo los posicionó entre el público. Para ciertos hogares, fueron "entrañables y durables" 42 , al ser uno de los pocos elementos de ornato a su alcance.

La variedad de los tamaños de los calendarios facilitó que pudieran ser lucidos en distintas partes de las casas, las oficinas, las carnicerías, las panaderías. Según el lugar al que fueran destinados podían despertar todo tipo de sentimientos (nostalgia, ensoñación, romanticismo, erotismo), pues una fábrica de aceites podía destinarlos a talleres mecánicos, una de cervezas a cantinas y una de refrescos a las decenas de miles de tienditas de la esquina ${ }^{43}$. A la par de este aspecto relacionado con la mercadotecnia, es pertinente mencionar que, por lo menos durante un cuarto de siglo, hubo decenas de pintores contratados para crear esas atractivas ilustraciones y cuya autoría hoy es casi anónima. Hasta la fecha, pocas personas identifican nombres tan destacados como los de Aurora Gil, Jesús Helguera, Vicente Morales, Eduardo Cataño Wihelmy, Alberto Carmona, Mariano Miguel, José Bribiesca, Alfredo González, Antonio Gómez y Rodríguez, Mario Chávez Marión, Humberto Limón, Héctor Ladrón de Guevara, Luis Améndola, Santiago Sadurní, Ángel Martín Merino y muchísimos más que ni siquiera firmaban sus diseños. Y quienes sí fueron reconocidos (Armando Drechsler, Jorge González Camarena o Josep Renau), trabajaron poco en ese giro, el cual consideraban una labor de estricta supervivencia. Las temáticas de

arte de los calendarios mexicanos del siglo XX en Galas de México (México: Museo Soumaya, Telmex, 2000), 9-33; Ángela Villalba, Mexican Calendar Girls/Chicas de calendarios mexicanos: Golden Age of Calendar Art: 1930-1960/ La época de oro del arte de los calendarios: 1930-1960 (San Francisco: Chronicle Books, 2006); Armando Bartra, Sueños de papel. El cartel cinematográfico mexicano de la época de oro (México: UAM-X, Filmoteca de la UNAM, 2010); Carlos Monsiváis, "Jesús Helguera: el encanto de las utopías a domicilio", en Jesús Helguera, El calendario como arte (México: SEP, SRE, 1987), 7-12; Elia Espinosa, Jesús Helguera y su pintura, una reflexión (México: UNAM, Instituto de Investigaciones Estéticas, 2004); Maricruz Castro Ricalde, "Ninón Sevilla", 604-617; Maricruz Castro Ricalde, "Prestamos e intercambios: el cine de la Época de Oro en la gráfica popular mexicana", en Mexican Transnational Film and Literature, edits. Maricruz Castro Ricalde, Mauricio Díaz Calderón y James Ramey (Oxford: Peter Lang), 103-122.

42 Bartra, Sueños, 73.

43 Una cervecería podía encargar hasta 200 mil unidades que eran repartidas en el mayor número posible de cantinas de pueblos. Villalba, Mexican Calendar Girls, 18. 
los cromos funcionaron como una "patria portátil", según la acertada expresión de Alfonso Morales ${ }^{44}$.

Como sucedió con la celebración de la "Noche Mexicana" de 1921 y sus artículos periodísticos, los cromos de los calendarios persistieron en los estereotipos sobre Yucatán, sus espacios, sus costumbres y su gente. Como aquellos, subrayaron la lejanía geográfica y cultural que separaba esta región del resto del país aunque ya no por delimitar las orillas costeras del mismo. De lo que estos impresos dan cuenta, sin proponérselo, es de cómo sin recurrir a la iconografía de palmeras, mar y arena presentan el componente identitario caribeño no en los elementos "transparentes" de la imagen sino en los menos visibles, en los más opacos.

La obra que deseo presentar es la de uno de los pintores más reconocidos de esa industria, Jesús Helguera. Se trata de "Xtabay" que también fue conocida como "Caminante del Mayab". La pintó en 1943 para los calendarios de la compañía tabacalera "La Moderna", empresa para la que trabajó casi en exclusiva a través del negocio de Santiago Galas ${ }^{45}$. En ella, Helguera retoma la canción escrita por Antonio Mediz Bolio y musicalizada por Guty Cárdenas, quien vivía un gran éxito y reconocimiento del público en 1932, año de su temprana muerte ${ }^{46}$. La composición era popular tanto por sus méritos musicales como por embonar perfectamente en el período de la búsqueda de elementos nacionales provenientes de las regiones ${ }^{47}$. La mención en maya de la fauna yucateca

44 Morales, "La patria portátil”, 25.

45 Espinosa explica que esta empresa encargaba "dos óleos de gran formato por año", los cuales pasaban a formar parte de la colección del dueño de la tabacalera. Hay indecisión sobre la fecha de creación de esta pintura, pues mientras en algunos catálogos es de 1943, Espinosa la fecha en 1945. Espinosa, Jesús Helguera, 166. Su paradero es desconocido. Lo que es indudable es que pertenece a la primera época de la obra de Helguera para Galas de México, dada la similitud de los cuerpos indígenas, de los paisajes (los volcanes) y la paleta cromática, en general.

46 Miguel Civeira Taboada, Sensibilidad yucateca en la canción romántica. II (Toluca: Gobierno del Estado de México, Fonapas, 1978), 366-368.

47 José Emilio Pacheco recuerda la necesidad de reivindicar, en el marco de la microhistoria, la relevancia de la lírica popular que hasta antes de mediados del siglo XX era de consumo cotidiano y que fue cayendo en un injusto olvido. De aquí la necesidad de resaltar la autoría de Mediz Bolio, detrás de los ritmos de Guty Cárdenas en "Caminante del Mayab". José Emilio Pacheco, "El retorno de la poesía popular”, Letras Libres (México, 2000), 31-33. http://www.letraslibres.com/sites/default/ 
fue un recurso poético eficaz para que eso ocurriera: "Caminante, caminante,/ que vas por los caminos,/ por los viejos caminos/ del Mayab. Que ves arder de tarde/ las alas del Xtakay;/ que ves brillar de noche/ los ojos del cocay. Caminante, caminante,/ que oyes el canto triste/ de la paloma azul,/ y el grito tembloroso/ del pájaro pujuy." Y el siguiente atributo que la convirtió casi en un himno para la región fue la segunda parte de la canción, la cual parafrasea y resume la famosa leyenda maya de la "Xtabay": 48 "Caminante, caminante,/ me has de decir si viste/ aparecer/ como una nube blanca/ que vino y que se fue/ y si escuchaste un canto/ como voz de mujer. Caminante, caminante,/ también en mi camino/ la nube blanca vi,/ también escuché el canto/ pobrecito de mí."

Helguera distingue la leyenda dentro de la letra de la canción y muy posiblemente esta le da pie para imaginar a esa hechicera seductora, inasible, "como una nube blanca". La obra que produjo para los calendarios es significativa por varios motivos. Por una parte (y como antes habían dado fe los reportes sobre la "Noche Mexicana" de 1921), es un ejemplo de cómo el concepto de "autenticidad" pasaba a un segundo término para privilegiar el de una estética que complaciera los imaginarios existentes y, al mismo tiempo, introdujera otros compatibles con estos. Los modelos de belleza femeninos así como los musculosos cuerpos masculinos siguen los estándares de belleza europeos y estos prevalecerán sin importar si a quienes se desea retratar sean de origen indígena o mestizo. Con mayor razón, en este cuadro, en el que el personaje femenino es un ser mágico que esquiva coquetamente el roce del caminante. Se fortalece también un imaginario en relación con la apariencia indígena, la cual es uniforme e intercambiable. La náhuatl será el modelo (que

files/files6/files/pdfs articulos/pdf art 6317 5904.pdf (fecha de consulta: septiembre de 2017).

48 El personaje es mencionado por Fray Diego de Landa y en el siglo XIX, de acuerdo con el espíritu romántico de la época, resurge con fuerza singular. Los elementos básicos de la leyenda son retomados por los principales analistas de la literatura yucateca desde esa centuria. Mary Preuss, "Un bosquejo de la violencia en la literatura maya-yucateca", Scripta Ethnologica Vol. XXIV Nº 26 (2004), 69-70. 
además es desde donde se creaban las pinturas que fueron la base de las miles de reproducciones en offset que circularon $)^{49}$.

La precisión del paisaje tampoco parecería importar demasiado: ni el relieve, ni el suelo, ni la flora, coinciden con los de Yucatán. Las montañas del fondo, los enormes árboles y la tupida vegetación corresponden más a la de los bosques europeos y no a las características de la selva baja existente en la península yucateca. Los traslapes de temas mexicanos con elementos tan relacionados con el llamado Viejo Continente se explican, por lo menos parcialmente, en función de la biografía del artista: formado en España, fue profesor de arte en Bilbao y regresó a México, huyendo de la Guerra Civil ${ }^{50}$. De aquí que estén presentes la flora del norte de la península ibérica, la mitología celta (tan cercana a la sensibilidad vasca) y giros pictóricos propios del prerrafaelismo, el cual reapareció en la arquitectura y el diseño gráfico art nouveau con el que creció el artista.

El proceso para la realización de la pintura manifiesta la convicción de que apelar al pasado indígena podría ser del interés de un amplio público. Si bien el tema podía ser propuesto por el artista (o provenir de la propia empresa), solo se concretaba si un comité lo aprobaba. Si así ocurría, un equipo (el guionista, dos camarógrafos y el artista) viajaba al lugar designado para tomar "abundantes fotografías de paisajes, flora y fauna, artesanías, arquitectura" ${ }^{2}$. Es poco probable que algo de eso hubiera ocurrido para que Helguera materializara esta obra. Es decir, evidentemente nada de lo que está a la vista en "Xtabay" tiene su origen en Yucatán y es más lógico asumir que algunas vistas recogidas para pintar "La leyenda de los volcanes" fueron la base plástica de la leyenda maya que recreó. Su inclusión dentro del catálogo de La Moderna indica que

49 Ejemplos paradigmáticos provendrán de su primera serie "La leyenda de los volcanes", a partir de la cual será imposible distinguir qué etnia indígena está retratando. Pensemos en sus obras "Amor indio" o "Flechador del cielo". Estas ilustraciones contribuirán a homogeneizar la apariencia de las etnias mexicanas y centroamericanas, en general, debido a que Galas distribuyó mucho tiempo sus impresos fuera del país.

50 Espinosa, Jesús Helguera, 26-27.

51 Monsiváis, "Jesús Helguera", 9. 
los imaginarios circulantes admitieron como genuinos los absurdos elementos seleccionados por el hoy reconocido ilustrador.

Helguera robustece, por tanto, los procesos creativos que databan desde la época colonial y que fueron estimulados en el porfiriato, en los que lo europeo se imponía en los territorios invadidos. El paisaje hiperrealista confiere verosimilitud a la mujer que ha aparecido y ambos se proponen como expresión de la belleza a la cual se aspira. La figura femenina pareciera elevarse envuelta en la nube de su ropaje; su coqueteo y gesto que la ponen fuera del alcance maya podría interpretarse como una alegoría del deseo indígena, el cual estriba en poseer aquello tan distinto a sí mismo. Y, sin embargo, al mismo tiempo este artífice de los calendarios fue uno de los puntales activadores de las representaciones de lo indígena, a partir de estos primeros cromos. Reprodujo mitos fundadores del mundo prehispánico y los insertó en versiones "bellas" que lograron una aceptación vastísima.

Con todo y esas imposturas, Helguera se alejó de los estereotipos de fealdad, suciedad, pereza, retraso y rechazo que se había extendido entre ciertos segmentos sociales, en relación con las etnias de México. En vez de ello, desplegó personajes con movimiento, inmersos en tragedias o momentos singulares, en medio de paisajes imposibles. Además hay que reconocer que su pintura es de las escasas representaciones visuales distintas a las que terminaron por consolidarse, justo en 1943, con la llegada de Jaime Torres Bodet a la Secretaría de Educación Pública: atuendos mestizos de la Colonia y escenas campiranas de la arcadia decimonónica. No es sino hasta que "las veleidades del mercado (de exportación) [comienzan] a exigir tópicos nuevos, cuando algunos regionalismos (el istmo, el sureste) [avanzan] hacia la primera fila" ${ }^{\prime \prime 2}$.

Las representaciones que alentaron las ideas sobre el exotismo de lo yucateco en los cromos de los calendarios fueron alimentadas por problemas como "el relativo aislamiento de la península, la aleatorie-

52 Sheridan, México, 42. 
dad y/o falta de transportes y la escasez de recursos del gobierno estatal" ${ }^{53}$. José Vasconcelos ya había aludido al "misterio" que envolvía a Yucatán, cuando lo visitó en $1921^{54}$, expresión que coincidía con las descripciones relacionadas con la magia de esa tierra, en las reseñas de la "Noche mexicana" de ese año. No extraña, pues, que basándose en el "enigma" y el "misterio" que entrañaban la cultura maya se lanzaran las primeras campañas de promoción turística, en los años treinta (cuyo título fue "El Egipto de América") ${ }^{55}$. El triunfo de estas imágenes como paradigma de Yucatán explica el desplazamiento de los imaginarios de la costa (que connotaba claridad y mar abierto) hacia el interior de la península, selvática y aún inexplorada; condiciones idóneas, en lo económico, para seducir a los turistas y en lo político, para situarla como una región singular con fuertes lazos con su pasado indígena.

Los títulos del material pictórico catalogado por Galas de México enfatizan tanto el ángulo identitario (a través del uso del gentilicio) como el lugar que se convirtió en el sinónimo de la península: la zona arqueológica de Chichén Itzá. Algunos de ellos son: "Yucateca" (Luis Osorno, 1944); "Chichén Itzá" (Luis Osorno, 1945); "Chichén Itzá" (Antonio Gómez y Rodríguez, mediados siglo XX); sin título (Mariano Miguel, 1948) 56; "Ofrenda" (anónimo, 1948); "Española y yucateca" (Gómez Arévalo, 1948); una obra sin título ni fecha de Antonio Gómez y Rodríguez y otra de José Bribiesca; "Boxita” (Chávez Marión, 1958).

53 Luis Anaya Merchant, "El Egipto de América. Yucatán y el olvido histórico en el nacimiento del turismo mexicano”, Memorias Vol. $10 \mathrm{~N}^{\circ} 23$ (2014): 68).

54 Novelo-Oppenheimer, De revoluciones, 183.

55 Anaya, "El Egipto", 67. Uno de los evaluadores de este artículo atinadamente indica que la imagen de Yucatán como "El Egipto de América", "fue tomada de los viajeros norteamericanos Channing Arnold y Frederick Tabor Frost, que estuvieron en Mérida entre 1906 y 1907 y que en 1909 escribieron The American Egypt. A Record of Travel in Yucatan". Puede revisarse también su traducción al español: Channing Arnold y Frederick Tabor Frost, El Egipto americano: testimonio de un viaje a Yucatán, trad. Roldán Peniche Barrera (Mérida: Instituto de Cultura de Yucatán, 2010).

56 Despliega la figura de una mestiza con el observatorio ("El Caracol”) de Chichén Itzá al fondo. Ver Figura 3. 
Figura 3

Yucatán y sus traslapes identitarios. "Sin título"

(Mariano Miguel, 1948, colección Galas de México).

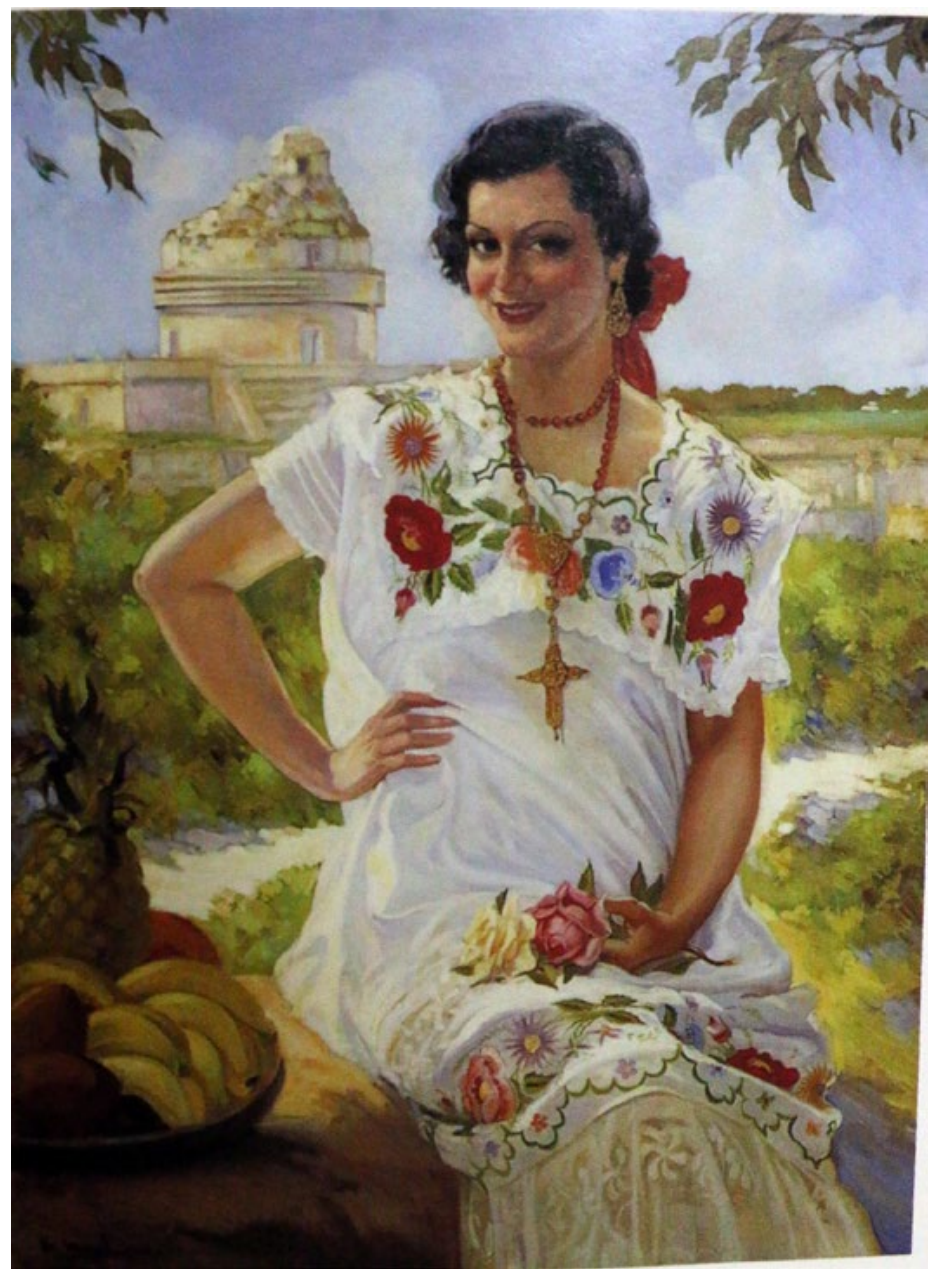

Imagen cortesía de: Museo Soumaya.

Aunque por limitaciones de espacio no puedo abordarlos todos, deseo dejar constancia de los tres tópicos que vertebran esas imágenes: Chichén Itzá como espacio constante; escenas del pasado prehispánico (un juego de pelota, una ceremonia solemne); el personaje de la mestiza como elemento central. Lo caribeño se aleja de su asociación más usual, el mar, y se interna al interior de la península, a la selva yucateca. La profusión vegetal invade las edificaciones de la ciudad maya, según puede 
apreciarse en la obra de Mariano Miguel (ver Figura 3). Artista madrileño, afincado en Cuba, fue un destacado grabador con una respetable carrera en La Habana. No he podido establecer las fechas en las que viajó a México, ni el tiempo de su estancia, aun cuando hay constancia de que montó por lo menos una exposición en ese país. Su interés por cuadros de la vida cotidiana en su patria adoptiva lo extendió a la obra pictórica que sirvió de base para algunos cromos de calendario ${ }^{57}$.

La familiaridad de Mariano Miguel con la región caribeña lo induce a integrar en la composición un platón de frutas: de manera destacada aparecen una piña y un racimo de plátanos; menos expuestas, una papaya y un par de zapotes. Aunque la piña no se cultiva en Yucatán, los imaginarios sobre el trópico, el calor y la fiesta la convierten en una presencia obligada. En medio de una antigua ciudad prehispánica que luce abandonada, "florece" la yucateca, cuyo terno de gala rinde honor a la exuberancia vegetal circundante. El "rodeo" semántico que realiza el artista para formar una suerte de "continuum" entre las islas y la península se basa, de manera evidente, en la naturaleza predominante en su obra; pero también evoca la herencia colonial hispana común así como la huella de la presencia indígena en ella ${ }^{58}$.

\section{Conclusión}

En síntesis, en las líneas anteriores expuse cómo Yucatán transitó de ser visto a partir de sus costas a ser circunscrito, básicamente, a Chichén Itzá. Cuestiones relacionadas con el turismo influyeron para que así fuera. Inquietudes de orden político, sobre todo, intervinieron para ligar destacadamente a Yucatán en el mosaico de las regiones. Al convertir el pasado indígena en el estandarte peninsular, el discurso del centro trastocaba aquello que había contribuido a su aislamiento y a una marcada diferenciación con otros enclaves del país para transformarlo en una pieza fundamental para articular el gran mosaico nacional.

57 Elizabeth Laguna Enrique, El Museo Nacional de Bellas Artes de La Habana y la colección de retratos de pintura española del siglo XIX (Salamanca: Ediciones Universidad de Salamanca, 2013), 307. fueron sus centros ceremoniales?, ¿podría ser esta mestiza de rasgos europeos (y que ocupa gran parte de la composición) un comentario visual acerca de la imposición occidental en las culturas de América? 
Los casos expuestos también me han permitido reflexionar sobre los supuestos esencialistas del estereotipo, su carácter homogeneizante y, al mismo tiempo, su articulación con valores compartidos y válidos para la totalidad del conglomerado social. El proceso de la formación de estereotipos regionales que contribuyó al triunfo de la nación recurrió, consciente o inconscientemente, a la simplificación, la alteración o la indiferenciación (lo indígena como un bloque carente de singularidad) que redundaba en una mezcla de elementos ajenos entre sí y que se presentaban como "auténticos". Este fue un proceso "transparente" y, por ende, ajeno a una "opacidad" reveladora de la diversidad y la heterogeneidad mexicanas y que reprodujo "la identificación de Yucatán exclusivamente en términos de su población maya" 59 .

La soledad de sus mestizas en zonas arqueológicas desiertas y abandonadas también proyectaba ideas similares a las de siglos anteriores ${ }^{60}$, en las que lo "vacío" del espacio y su baja densidad demográfica justificaba o el olvido político o el deseo desenfrenado de colonialización. Sin embargo, una lectura cercana al cromo de Mariano Miguel amplía los registros de la imagen e invita a leerlos en función de los múltiples aspectos existentes y que son comunes en el Caribe. La ciudad maya estática y abandonada se vitaliza con la variedad de frutas presentadas, a través de las cuales resuena el baile y la fiesta del trópico. El plato con alimentos frescos reanima el antiguo observatorio de Chichén Itzá y se transforma en el indicio contemporáneo de haber sido el centro de una gran civilización.

Obras gráficas como las analizadas estaban concebidas, desde su diseño, para ser desechadas más temprano que tarde; para ser entendidas como productos de reproducción masiva: una fotografía tomada ex profeso para un diario, un fotomontaje para publicitar una película, un cromo para un calendario. Ninguno de ellos formó parte del discurso "de arriba" ni en el plano intelectual ni en el artístico. Y, sin embargo, las imágenes que proyectaban se integraron, de manera fluida, a las ideas sobre un espacio dado. Finalizo, pues, al destacar cómo la cultura visual

59 Shrimpton, "Islas de tierra firme", 190.

60 Rosa Torres Conangla, R, “¿Diversas visiones de la nación?: disputas territoriales en la frontera sur de la península de Yucatán”, en Miradas regionales. Las regiones y la idea de nación en América Latina, siglos XIX y XX, comps. Jorge Arturo Taracena Arriola, María Carolina Depetris y Adam Sellen Temple (México: UNAM, 2013), 84. 
de una época invita a decodificar, desde la noción de "opacidad" de Glissant, la complejidad existente de los procesos históricos, los numerosos actores sociales que intervienen en ellos, la interrelación de propósitos que provienen desde las élites intelectuales así como la enorme riqueza que traen consigo las manifestaciones populares que circularon "desde abajo".

\section{Bibliografía}

\section{Fuentes primarias}

Agrasánchez Collection of Mexican Cinema, Benson Latin American Collection, the University of Texas at Austin Libraries. Caja 3, Fo. 17.

\section{Publicaciones periódicas}

“La 'Noche Mexicana' en el Bosque de Chapultepec”. El Universal Ilustrado, 29 de septiembre, 1921.

Manuel Palavicini. "La Noche Mexicana en Chapultepec", El Universal, Ciudad de México, 28 de septiembre, 1921.

\section{Cromo de calendario}

Mariano Miguel. "Sin título". Museo Soumaya, Colección Galas de México, cat. 134, 1948.

\section{Fuentes secundarias}

Anaya Merchant, Luis. "El Egipto de América. Yucatán y el olvido histórico en el nacimiento del turismo mexicano". Memorias Vol. 10 $\mathrm{N}^{\circ} 23$ (2014): 52-75.

-----. La gran depresión y México, 1926 1933. Economía, institucionalización, impacto social. Cuernavaca: UAEM, 2015.

Arnold, Channing, y Frederick Tabor Frost. El Egipto americano: testimonio de un viaje a Yucatán, trad. Roldán Peniche Barrera. Mérida: Instituto de Cultura de Yucatán, 2010.

Barke, Michael. "Merida, Yucatan: A core within the periphery". Scottish Geographical Magazine Vol. 100.3 (1984): 160-170.

Barna, Radu y Mircea Maniu. "Regional Identity: A prerequisite for any efficient change of the regional economic structure". Modelling the New Europe Vol. $20 \mathrm{~N}^{\circ} 3$ (2016): 3-23. 
Bartra, Armando. Sueños de papel. El cartel cinematográfico mexicano de la época de oro. México: UAM-X, Filmoteca de la UNAM, 2019.

Caisso, Claudia. "El caribe en sombras". Revista Universum Vol. 25 N 2 (2010): 13-28.

Cárdenas, Enrique. "La economía mexicana en el dilatado siglo XX, 1929-2009”. En Historia económica general de México, coordinado por Sandra Kuntz. México: El Colegio de México, 2010, 503548.

Castro Ricalde, Maricruz. "Ninón Sevilla, el Caribe y la publicidad gráfica de la edad de oro". Hispania Vol. 100 N$^{\circ} 4$ (2017): 604-617.

-----. "Prestamos e intercambios: el cine de la Época de Oro en la gráfica popular mexicana". En Mexican Transnational Film and Literature, editado por Maricruz Castro Ricalde, Mauricio Díaz Calderón y James Ramey. Oxford: Peter Lang, 2017, 103-122.

Civeira Taboada, Miguel. Sensibilidad yucateca en la canción romántica. II. Toluca: Gobierno del Estado de México, Fonapas 1978.

Cuéllar, Manuel R. "La escenificación de lo mexicano y la interpelación de un público nacional: la Noche Mexicana de 1921". En Mexican Transnational Film and Literature, editado por Maricruz Castro Ricalde, Mauricio Díaz Calderón y James Ramey. Oxford: Peter Lang, 2017, 123-140.

Cunin, E. "Negros y negritos en Yucatán en la primera mitad del siglo XX: Mestizaje, región, raza”. Península Vol. 4 Nº 2 (2009): 33-54. Dávila Valdés, Claudia. "Necesitamos extranjeros. Libaneses y coreanos en la sociedad yucateca". En Miradas regionales. Las regiones y la idea de nación en América Latina, siglos XIX y XX, compilado por Jorge Arturo Taracena Arriola, Ma. Carolina Depetris y Adam Sellen Temple. México: UNAM, 2013, 103-129.

Espinosa, Elia. Jesús Helguera y su pintura, una reflexión. México: UNAM, Instituto de Investigaciones Estéticas, 2004.

Ette, Ottmar, Werner Mackenbach, Gesine Müller y Alexandra Ortiz Wallner (Eds.). Trans(it)Areas. Convivencias en Centroamérica y el Caribe. Un simposio transreal. Berlín: edition tranvía · Verlag Walter Frey, 2011.

Gelpí, Juan. "El bolero en Ciudad de México: poesía popular urbana y procesos de modernización". Cuadernos de literatura Vol. 4 No. 7-8 (1998): 197-212.

Gellner, Ernest. Naciones y nacionalismo. México: Conaculta, 1991. 
Glissant, Édouard. Tratado del todo-mundo. Barcelona: El Cobre Ediciones, 1997.

Hale, Charles. La transformación del liberalismo mexicano en el último cuarto del siglo XIX. México: Editorial Vuelta, 1991.

Joseph, Gilbert. “Mexico’s 'Popular Revolution': Mobilization and Myth in Yucatan, 1910-1940". Latin American Perspectives Vol. $6 \mathrm{~N}^{\circ}$ 3 (1979): 46-65.

Joseph, Gilbert, Anne Rubenstein y Eric Zolov. "Assembling the Fragments: Writing the Cultural History of Mexico since 1940". En Fragments of a Golden Age: The Politics of Culture in Mexico Since 1940, editado por Joseph Gilbert, Anne Rubenstein y Eric Zolov. USA: Duke University Press, 2001.

Joseph, Gilbert, \& A. Wells. "Un replanteamiento de la movilización revolucionaria mexicana: los tiempos de sublevación en Yucatán, 1909-1915". Historia Mexicana Vol. XLIII No 3 (1994): 505-546. Laguna Enrique, Martha Elizabeth. El Museo Nacional de Bellas Artes de La Habana y la colección de retratos de pintura española del siglo XIX. Salamanca: Ediciones Universidad de Salamanca, 2013. López, Ricardo A. Crafting Mexico: Intellectuals, Artisans, and the State after the Revolution, Durham: Duke University Press, 2010. Mackenbach, Werner. "Del éloge de la creolité a la teoría del caos. Discursos poscoloniales del Caribe más allá de la identidad". Cuadernos Intercambio $\mathrm{N}^{\circ} 11$ (2013): 15-29.

Monsiváis, Carlos. "Jesús Helguera: el encanto de las utopías a domicilio"'. En El calendario como arte, editado por Jesús Helguera. México: SEP, SRE, 1987, 7-12.

Morales Alfaro, Jorge Antonio. “¿De qué manera la Gran Depresión afectó la política mexicana? 1929-1934”. La Gaceta de Ciencia Política Vol. 9 Nº 1 (2012): 89-97.

Morales Carrillo, Alfonso. "La patria portátil. 100 años de calendarios mexicanos". En La leyenda de los cromos. El arte de los calendarios mexicanos del siglo XX en Galas de México. México: Museo Soumaya, Telmex, 2000, 9-33.

Nivón Bolán, Eduardo y Xóchitl Ramírez Sánchez. "Identidad, nación y reforma del Estado en México". En La identidad nacional mexicana como problema político y cultural. Los desafíos de la pluralidad, coordinado por Raúl Béjar y Héctor Rosales. Cuernavaca: UNAM, CRIM, 2002, 297-330. 
Novelo-Oppenheim, Victoria. Yucatecos en Cuba. Etnografía de una migración. México: CIESAS/Instituto de Cultura de Yucatán, 2009.

-----. "De revoluciones y cambios culturales: Yucatán 1915-1929”. LiminaR Vol. $10 \mathrm{~N}^{\circ} 2$ (2012): 178-194.

Pacheco, José Emilio. "El retorno de la poesía popular", Letras Libres (México, 2000), 31-33. http://www.letraslibres.com/sites/default/files/files6/files/pdfs_articulos/pdf_art_6317_5904.pdf (fecha de consulta: septiembre de 2017).

Phaf-Rheinberger, Ineke, editor, "El lenguaje nación y la poética del acriollamiento. Una conversación entre Kamu Brathwaite y Édouard Glissant". En Memorias del silencio: literaturas en el Caribe y Centroamérica, comp. Graciela Salto. Buenos Aires: Corregidor, 2010, 17-45.

Pérez Montfort, Ricardo. "Ecos del Caribe en la cultura popular y en la bohemia yucateca, 1890-1920”. En El Caribe: región, frontera y relaciones internacionales, coordinado por Johanna von Grafenstein y Laura Muñoz. México: Instituto Mora, Conacyt, 2000, 160-186.

-----. Expresiones populares y estereotipos culturales en México. Siglos XIX y XX: diez ensayos. México: CIESAS, 2007.

-----. "Postales de la Antillas, Estereotipos y negros en la imagen comercial del Caribe, 1900-1950”. En Circulaciones culturales, Lo afrocaribeño entre Cartagena, Veracruz y La Habana, coordinado por Freddy Ávila Domínguez, Ricardo Pérez Montfort y Christian Rinaudo. México: Ciesas, IRD, ANR, Universidad de Cartagena, El Colegio de Michoacán, 2001, 115-146.

----- y Christian Rinaudo. "Introducción". En Circulaciones culturales, Lo afrocaribeño entre Cartagena, Veracruz y La Habana, coordinado por Freddy Ávila Domínguez, Ricardo Pérez Montfort y Christian Rinaudo. México: Ciesas, IRD, ANR, Universidad de Cartagena, El Colegio de Michoacán, 2001, 9-36.

Pinkus Rendón, Manuel Jesús. De la herencia a la enajenación. Danzas y bailes "tradicionales" de Yucatán. Mérida: UADY, 2005.

Preuss, Mary. "Un bosquejo de la violencia en la literatura maya-yucateca". Scripta Ethnologica, Vol. XXIV N² 26 (2004): 67-76.

Pulido Llano, Gabriela. "Atmósferas tropicales y pieles al carbón”. Revista de la Universidad de México Nº16 (2002): 33-39. 
Mulatas y negros cubanos en la escena mexicana 1920-1950. México: INAH, 2010.

Rogoff, Irit. "Studying Visual Culture". En The Visual Culture Reader, editado por Nicholas Mirzoeff. London: Routledge, 2002.

Rubin, Jeffrey W. "Descentrando el Régimen: Cultura y Política regional en México". Relaciones. Estudios de historia y sociedad Vol. XXIV N 96 (2003): 125-180.

Shrimpton Masson, Margaret. "Islas de tierra firme: ¿un modelo para el Caribe continental? El caso de Yucatán”. Memorias Vol. $11 \mathrm{~N}^{\circ}$ 25 (2015): 178-208.

Sheridan, Guillermo. México en 1932: la polémica nacionalista. México: Conaculta, Ediciones sin nombre, 2004.

Schuessler, Michael, "Estudio preliminar". En Alma Reed. Peregrina. Mi idilio socialista con Felipe Carrillo Puerto. México: Diana, 2006, XIII-LXXII.

Torres Conangla, Rosa. "¿Diversas visiones de la nación?: disputas territoriales en la frontera sur de la península de Yucatán”. En Miradas regionales. Las regiones y la idea de nación en América Latina, siglos XIX y XX, compilado por Jorge Arturo Taracena Arriola, Ma. Carolina Depetris y Adam Sellen Temple. México: UNAM, 2013.

Velázquez Becerril, César Arturo. "Intelectuales y poder en el Porfiriato. Una aproximación al grupo de los Científicos, 1892-1911”. Fuentes Humanísticas Vol. $41 \mathrm{~N}^{\circ} 1$ (2010): 7-23.

Villalba, Ángela. Mexican Calendar Girls/Chicas de calendarios mexicanos: Golden Age of Calendar Art: 1930-1960/ La época de oro del arte de los calendarios: 1930-1960. San Francisco: Chronicle Books, 2006.

Wells, A., \& Joseph, G. M. Summer of discontent, seasons of upheaval: Elite politics and rural insurgency in Yucatan, 1876-1915. Stanford: Stanford University Press, 1996.

Wilson, S. M., Iceland, H. B., \& Hester, T. R. "Preceramic connections between Yucatan and the Caribbean". Latin American Antiquity Vol. $9 \mathrm{~N}^{\circ} 4$ (1998): 342-352.

Para citar este artículo: Castro Ricalde, Maricruz. "Opacidad y transparencia del Caribe en las representaciones de Yucatán. Dos casos de cultura visual", Historia Caribe Vol. XV No. 37 (Julio-Diciembre 2020): 119-150 DOI: http:// dx.doi.org/10.15648/hc.37.2020.6 